\title{
Divestments in Banking. Preliminary Evidence on the Role of External Factors
}

\author{
Krzysztof Jackowicz', Oskar Kowalewski²
}

ABSTRACT

Divestment constitutes an important method of corporate restructuring. Despite this fact, the banking literature on divestment is very limited. In this text, we try to remediate partially to the shortcomings of the existing literature by examining empirically the role of external factors. Using a large sample of 313 transactions, we have established that parent companies originate from countries with relatively high accumulated wealth, slow GDP growth, stable macroeconomic situation and dominant bank intermediation in financial system. The acquirers in turn come from poorer countries with faster economic growth and relatively more market-oriented financial systems. Those results broadly conform with the predictions of three hypotheses formulated in the text, namely the weak performance hypothesis, the corporate governance hypothesis and the rebalancing hypothesis.

KEY WORDS: $\quad$ divestment, banking, external factors

JEL Classification: G21; G34

\footnotetext{
${ }^{1}$ Kozminski University, Poland

${ }^{2}$ Warsaw School of Economics, Poland
}

\section{Introduction}

Divestments in banking mainly take the form of the subsidiary sell-offs. They constitute, as Brauer (2006) notices, the element of corporate portfolio restructuring alongside dissolutions and consolidation activity. They have far-reaching consequences. Divestments affect industry structures and competition, firm strategy and performance, employees' motivation and commitment. The literature on divestments is unbalanced. The studies on non-financial firms are numerous, whereas those on financial intermediaries are very rare. This is why we have undertaken a long-term research project concerning divestments in banking. This article presents preliminary evidence on the role played in this

Corespondence concerning to this article should be addressed to: kjtrist@kozminski.edu.pl process by external factors. By the external factors, we mean macroeconomic variables and variables characterizing financial system.

The reminder of the article is organized as follows. Section 1 introduces the literature review. Section 2 describes the dataset and our theoretical expectations. In section 3, we present the empirical results. The last section presents the conclusion.

\section{Literature Review}

\subsection{Banking literature.}

As we have already mentioned, the banking literaturedealing with the problem of divestment is very limited . We are aware of only three studies in this field. Leung et al. (2008) constructed a theoretical model of the entry and exit decisions based on the differential returns in a host and home market. Using this model, they empirically examined the entry and exit 

found that generally sell-off announcements are positively received by capital markets. On the event day, the mean abnormal return equals $0.85 \%$. The increase in shareholder wealth is larger when the completion of divestiture is announced and the transaction price is declared. The abnormal return is also positively influenced by the size of the divestment process. Moreover. financial problems of the divesting company play an important role. The weaker the financial condition of the seller, the greater is the abnormal return on the event day. This relationship supports the hypothesis that some divestments are regarded as bankruptcy avoidance methods.

Guedes \& Parayre (1997) remarked in turn that market reactions depend on the performance of the division being sold. They identify 370 events of divestment announcements in the U.S. For the entire sample, the stock market return is $1.6 \%$ and statistically significant. However, for the subsample of successful divisions, the market reaction is stronger $(2.5 \%)$ and again statistically significant. In contrast, when firms announce their intention to sell under-performing divisions, the stock market return is not statistically distinguishable from zero. Guedes \& Parayre explained this phenomenon by the full market anticipation of the attempts to sell losing divisions.

Gleason et al. (2000) broadened the analysis of divestment wealth effects since they examined abnormal returns for sellers and acquirers. The sample encompasses 244 foreign divestments initiated by U.S. multinational corporations in the 1980-1996 period. Gleason et al. documented that the capital market judges both sales and purchases of divested entities as valueenhancing. The abnormal return recorded by acquirers and sellers equals to $0.48 \%$ and $0.65 \%$, correspondingly. Market reactions are positively related to leverages and measures of efficient asset utilization.

\subsubsection{Consequences.}

Conglomerates in the mature economies are usually traded at a discount in comparison with the portfolio of undiversified firms. Burch \& Nanda (2003) argued that this discount can be ascribed to the diversity in investment opportunities that exacerbates agency problems. They analyzed 106 spin-off transactions initiated by U.S. companies during the 1979-1996 period and found that the reduction in diversity plays an impor- tant role in explaining the market value gains to spinoffs. Ahn \& Denis (2004) obtained similar results as far as relative investment inefficiency of diversified firms is concerned. Their sample is composed of 150 spin-offs completed by U.S. firms between 1981 and 1996. They demonstrate that after the divestiture, the discount, at which diversified companies are traded, disappears. Ahn \& Denis pointed to the improvement in investment allocation as an explanation for this phenomenon.

Çolak \& Whited (2007) challenged the findings of earlier studies that divestments led to the improvements in investment efficiency. They hypothesized that these analyses suffered from endogeneity and measurement problems. Using the database covering 154 spin-offs and 267 divestitures, they showed that the same factors are responsible for inducing firms to sell assets and to increase investment efficiency. Hence, spin-offs and divestitures do not cause improvements in the investment efficiency, but simply coincide in time with these improvements.

\subsubsection{Other issues.}

The existing literature on divestiture in the field of corporate finance, as we have mentioned, concentrates on three topics: the motives for the decision to divest, the wealth effects of this decision and its consequences for investment efficiency. Owen \& Yawson (2006) investigated instead the decision where to divest and they filled an evident gap in the literature. They analyzed 345 Australian companies, which in the period spanning from 1992 to 2003, sold at least one domestic or international subsidiary. They documented that Australian parent companies are more likely to sell a subsidiary overseas when these companies have a large scale of operations, offer low dividend yields and are highly geographically diversified. Aditionally, Owen \& Yawson presented evidence supporting the hypothesis that overseas divestiture operations aim at concentrating on core business areas.

\section{Data and Theoretical Expectations}

We have gathered data on 313 divestment transactions in banking around the world, which took place between 1997 and 2010. The number of transactions per year fluctuated between 8 in 1997 and 34 in 2003. In 170 cases, we were also able to collect information 
concerning deal values. The data about divestments were retrieved from the Zephyr database compiled by Bureau van Dijk, the data on macroeconomic trends and on financial systems from the World Bank databases: the World Development Indicators and Finan- cial Structure. As Figure 1 illustrates, the distribution of shares sold is highly skewed and dominated by total withdrawals out of the foreign markets. In our sample, parent companies sold 233 times 100\% stakes in foreign banking subsidiaries.

Figure 1. Empirical distribution of stakes sold

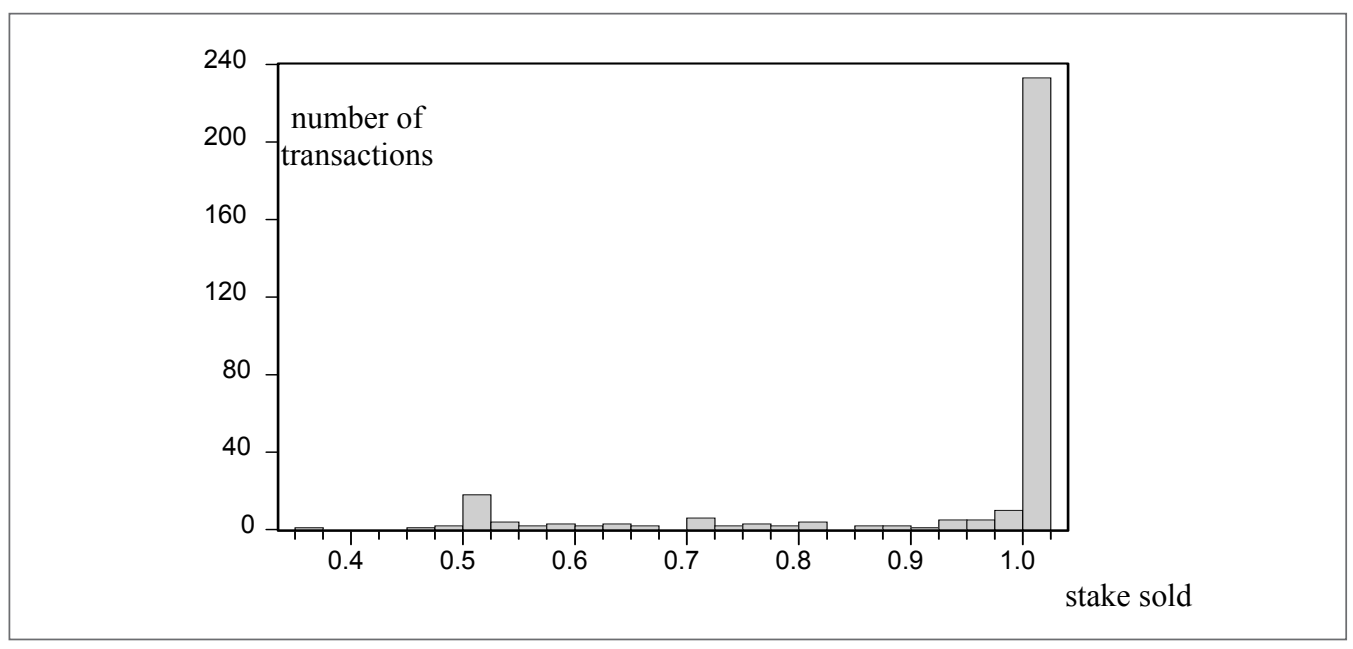

Source: Own study.

The mean value of divestment transactions (in the subsample of 170 deals) equals to 627 million euros, the median value is much lower and equals to 78 million euros. This difference suggests again a skewed character of the appropriate empirical distribution. Figure 2 , showing the distribution of deal values, confirms this hypothesis. As expected, the divestment process encompasses mainly relatively low value transactions (under 2 billion euros).

On the basis of the literature findings and the general economic knowledge, we advance three hypotheses about the role of the external factors in the divestment processes. Firstly, the literature strongly suggests that the portfolio restructuring is stimulated by weak performance. In banking, a decline in profitability is frequently connected with unfavorable macroeconomic trends. Therefore, we expect that countries, from which parent companies, i.e. sellers, originate, should be characterized by slower growth and higher unemployment. Shortly, we will call this preposition the hypothesis of weak performance. Secondly, the literature documents that corporate governance mechanisms play an important role in corporate diversification and refocusing. Hence, we predict that sellers, especially in the second part of the period under study, should come from countries with weaker managerial discipline, i.e. countries dominantly with financial systems based on financial intermediation. We will name this preposition as the corporate governance hypothesis. The final hypothesis of global rebalancing relies on the assumption that divestments should reflect the changes in relative economic power in the world. This is why we forecast that acquirers should originate from countries with lower accumulated wealth, less stable economies but higher GDP growth than in the parent companies from the countries of origin.

\section{Results}

\subsection{GDP growth and level}

The real GDP growth is the slowest in the group of countries, where parent companies are chartered. The mean real GDP growth in the parent company 
Figure 2. Empirical distribution of deal values (in million euros)

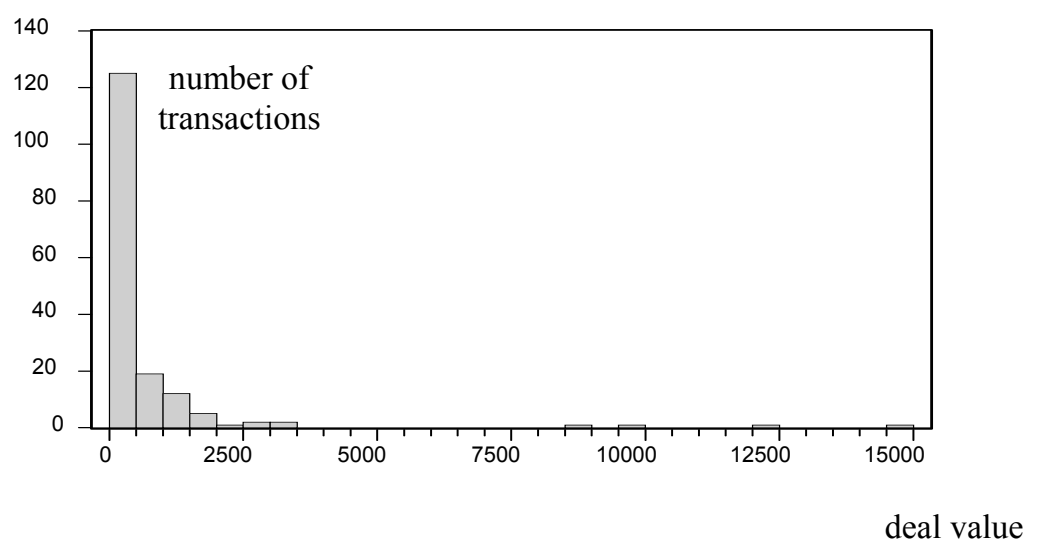

Source: Own study.

countries, as indicated by Panel A of Table 1, is one percentage point lower than in the acquirer countries and more than 1.5 percentage point lower than in the countries hosting the subsidiary entities. All the differences are statistically significant at the $1 \%$ or $5 \%$ level. The identified relationships among GDP growth rates are stable in time. As Figure 3 documents, the growth rates in countries, where subsidiaries and acquirers are located, almost always exceed those registered in countries of the parent companies. Those results are generally consistent with our hypotheses of weak performance and rebalancing. They come also as no surprise since obviously parent companies originate mainly from mature economies. Additionally, they suggest that the decision to sell a subsidiary could be related to the situation in the owners' country and does not have to be determined by the bad economic perspectives in the country, where a subsidiary operates.

GDP per capita adjusted for differences in purchasing power is the highest in the parent companies' countries of origin. As Panel B of Table 1 shows, its mean value there reaches 29 thousand US dollars and is almost 10 thousand US dollars higher than in the group of countries, where subsidiary entities are located. The mean value of GDP per capita for acquirer's countries is situated in the middle of this range and equals to 24 thousand US dollars as forecasted by the rebalancing hypothesis. The wealth discrepancies among the analyzed groups of countries constitute, as Figure 4 proves, a stable phenomenon. We find the only noticeable exception to this rule in the first three years of the studied period.

\subsection{Financial system characteristics}

The banks sold originate mainly, as illustrated by Figure 5 and Panel $\mathrm{C}$ in Table 1, from countries with a relatively modest level of financial intermediation. The mean ratio of banking sector assets to GDP in these countries equals $79 \%$ and is statistically significantly lower than in the other two groups examined in our study. As predicted by the corporate governance hypothesis, selling parties in turn operate in the economies with the highest level of financial intermediation. The mean ratio of banking sector assets to GDP largely surpasses in those countries by $100 \%$.

In our sample, buyers come predominantly from the economies with well-developed open financial markets. Acquirers' countries record, as documented by Figure 6 and Panel D of Table 1, the highest ratios of stock market capitalization to GDP. However, in contrast to the case of the banking sectors, the differences in the means are not so striking. In reality, the difference between countries, where parent companies operate, and acquirers' countries is not statistically significant and the differences calculated using the data from countries, where subsidiaries do business, are statistically 
Table 1. Mean values of the characteristics of the countries investigated and the test for equality of means

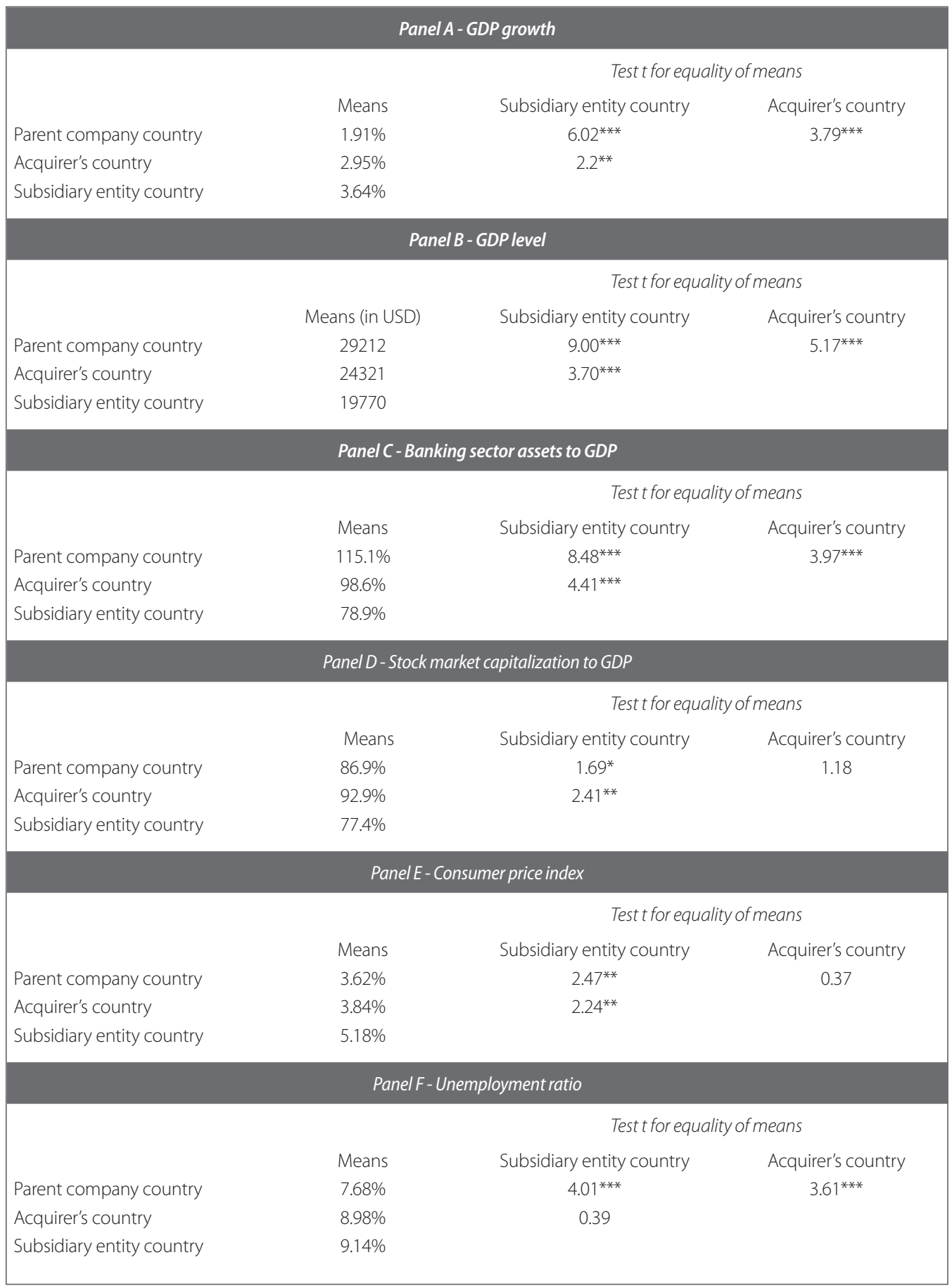


Figure 3. Mean GDP growth rates in consecutive years

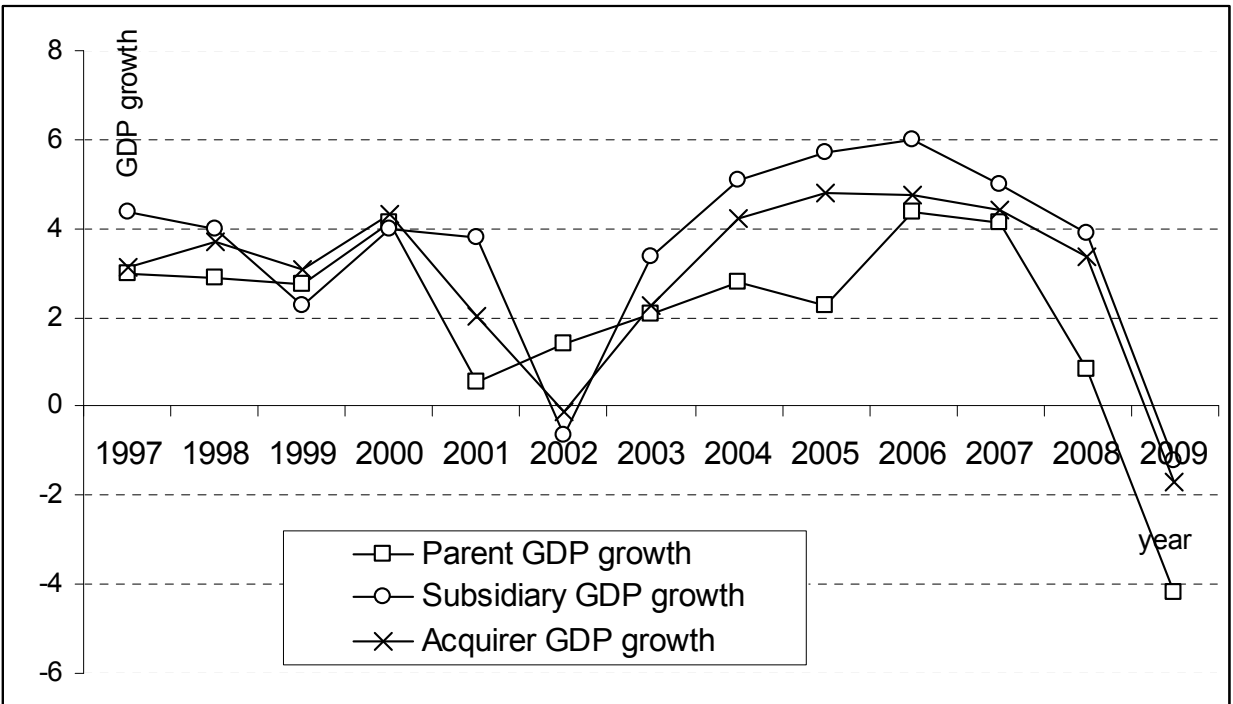

Source: Own study.

Figure 4. Mean GDP per capita adjusted for differences in the purchasing power for subsequent years.

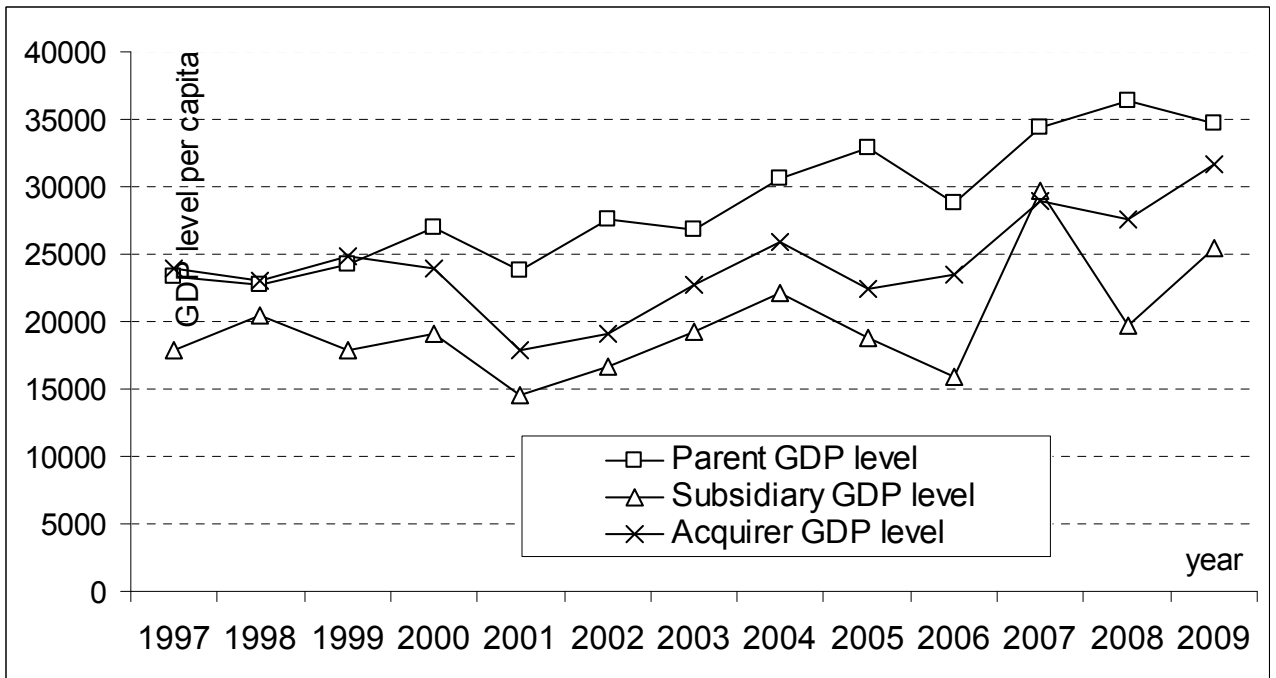

Source: Own study. 
Figure 5. Mean ratio of banking sector assets to GDP (in \%) in consecutive years

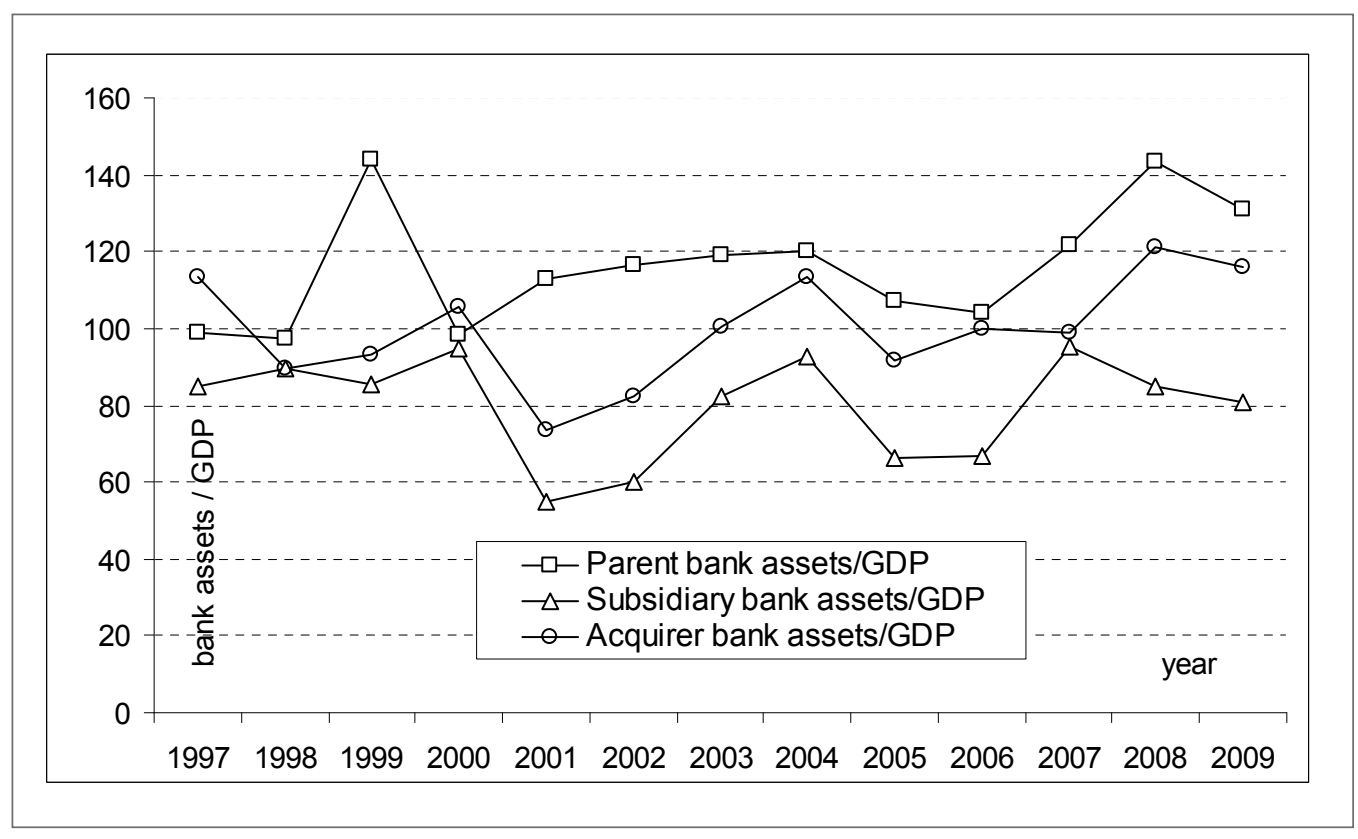

Source: Own study.

significant only at the $5 \%$ or $10 \%$ levels. Moreover, it is worth stressing that both Figure 6 and Figure 3 clearly show that modern economies and their financial markets are generally strongly correlated.

\subsection{Macroeconomic stability}

We have already documented that countries, where the sold subsidiaries operate, are characterized by the highest real GDP growth. Figure 7 and Panel E of Table 1 show that those countries exhibit also the fastest inflation. The mean CPI equals for them $5.18 \%$ and it is statistically significantly higher at the $5 \%$ level than in the other two groups of countries. The difference in means between sellers' and buyers' countries, on the one hand, and countries hosting subsidiaries, on the other hand, amounts to 1.5 percentage point. Thus, the acquirers countries, contrary to the rebalancing hypothesis, are not statistically less stable than parent company countries as far as price dynamics is concerned.

The same line of reasoning, as in the case of inflation, can be applied to the second measure of macroeconomic stability we use, i.e. unemployment ratio. The means of unemployment ratio are presented in
Panel F of Table 1. The evolution in time of this measure is described by Figure 8. Once again, the countries, where sold subsidiaries are chartered, are the most unstable. However, the differences in means - as far as their economic significance is considered - are not extremely important. They do not surpass 1.5 percentage point. Although the economic significance of differences in means is limited, in 2 out of 3 cases, the differences are statistically significant. The hypothesis of the weak performance this time is not supported by our empirical results since parent companies are chartered in countries, where on average, the unemployment rate is the lowest.

The empirical evidence of countries, from which parent companies originate, and of countries, where subsidiaries operate is somewhat puzzling. The former group of countries reports the lowest GDP growth ratios and, at the same time, the lowest unemployment ratios. The opposite is true for the latter group of countries. We think that this anomaly can be explained by the historical economic heritage. Some of the developing countries hosting subsidiaries simply started with the elevated unemployment ratios. 
Figure 6. Mean stock market capitalization to GDP (in \%) in consecutive years

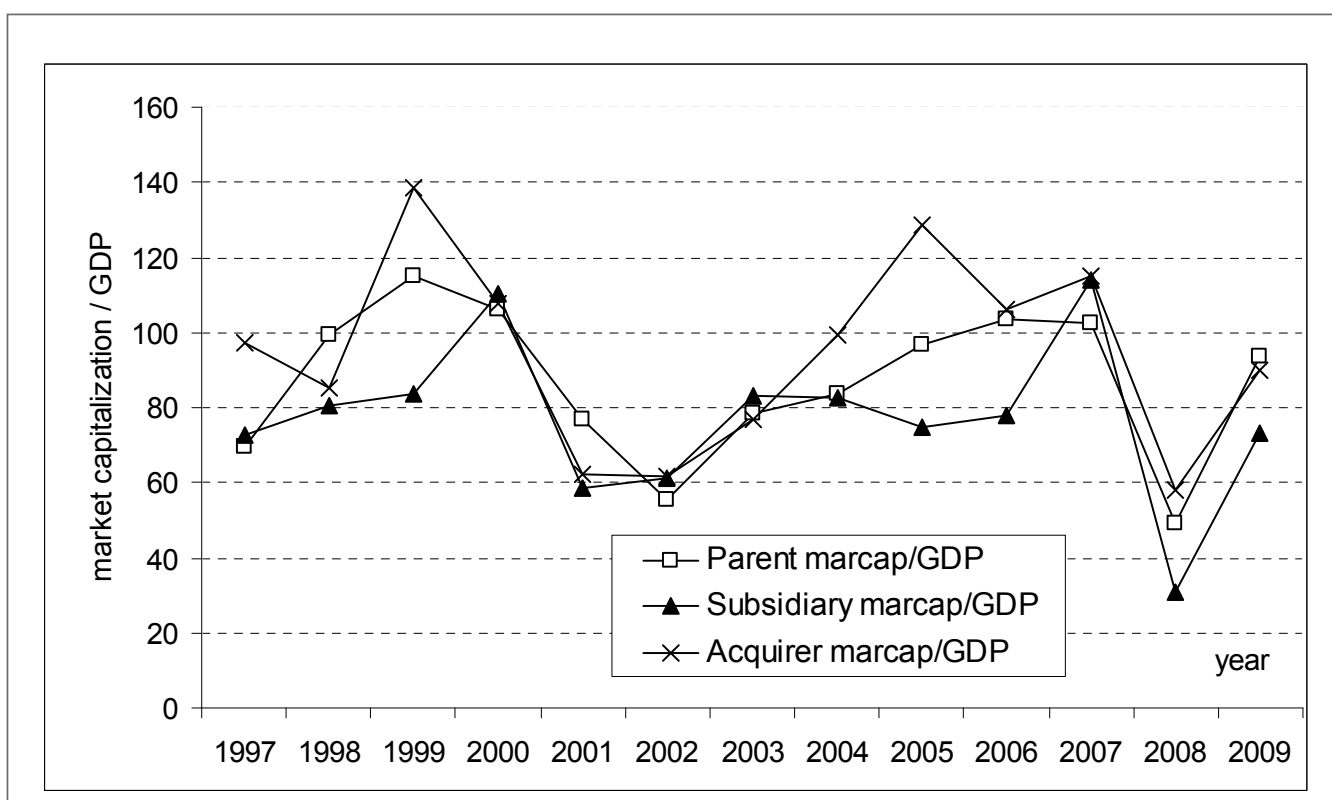

Source: Own study.

Figure 7. Mean consumer price indexes (CPI) in consecutive years

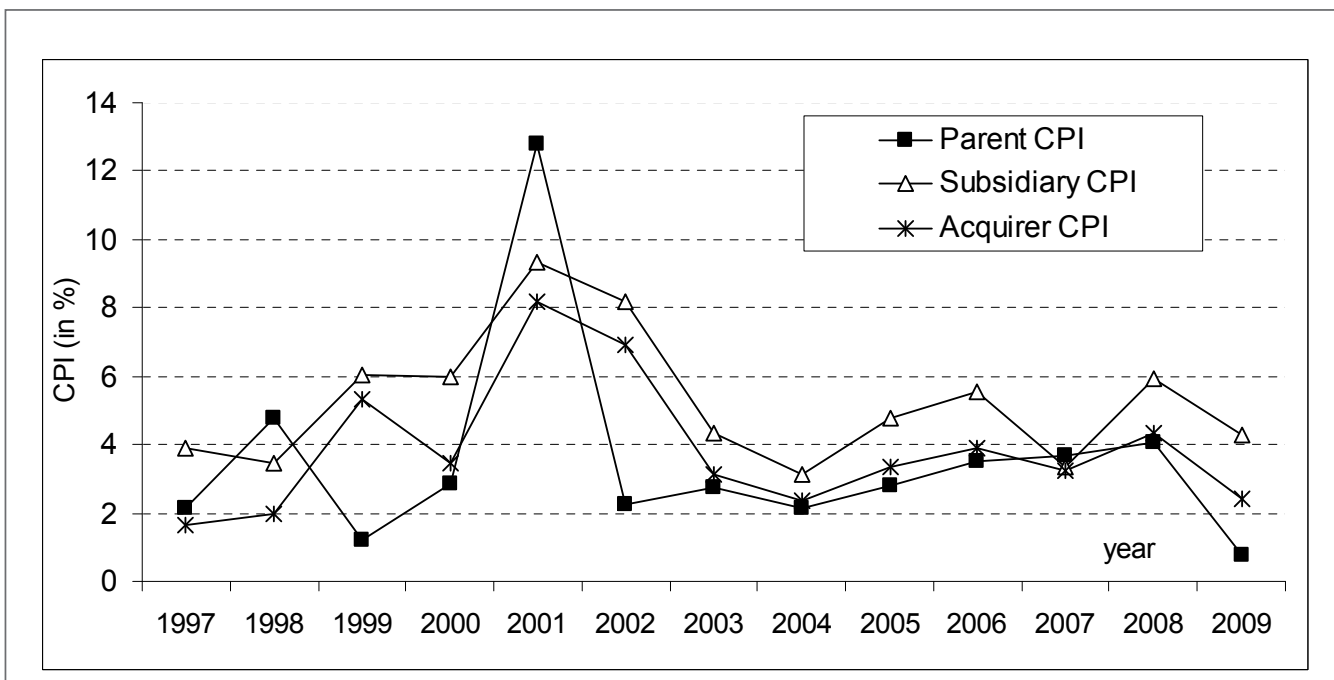

Source: Own study. 
Figure 8. Mean unemployment ratios in consecutive years.

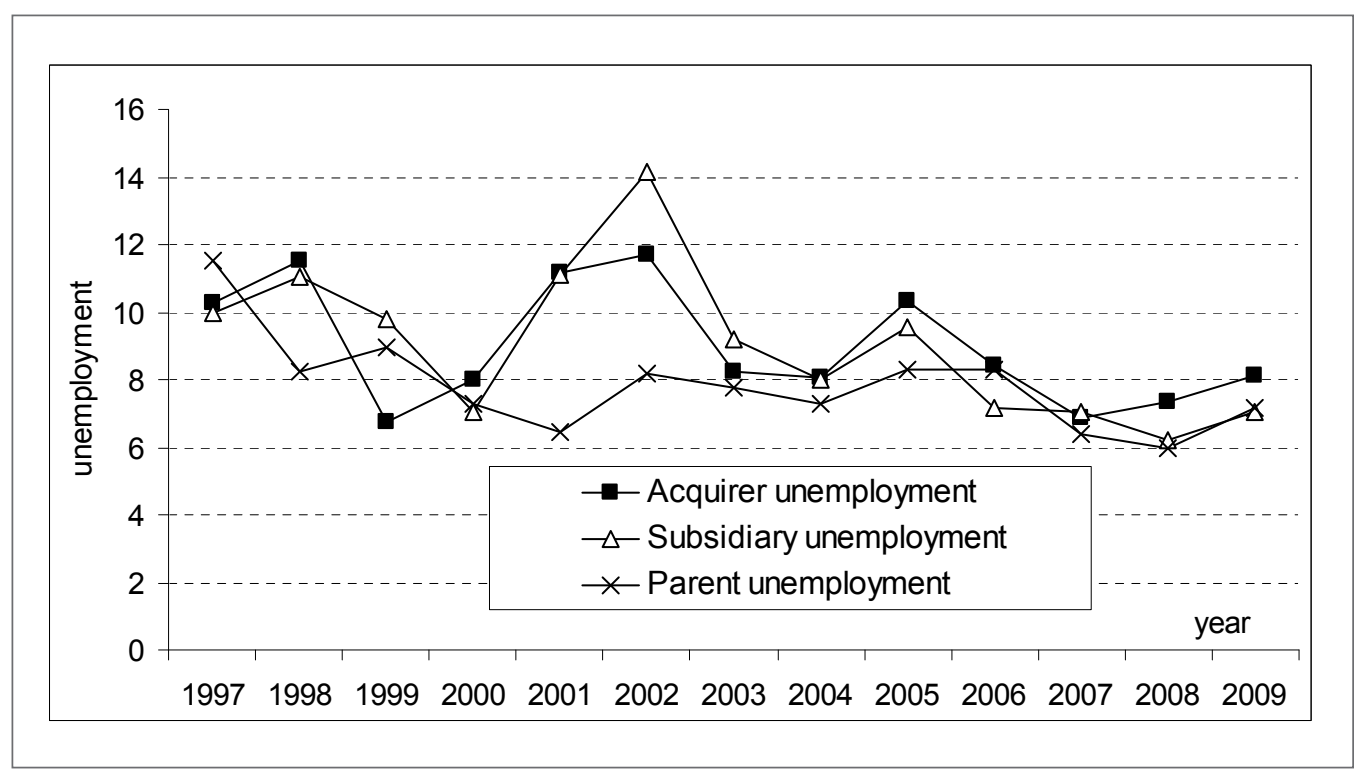

Source: Own study.

\section{Conclusions}

In the article, we provide preliminary evidence on the role of external factors in the divestment process in banking. Using a large sample of 313 transactions, we have established that parent companies (selling parties) originate from countries with a relatively high accumulated wealth, slow GDP growth, stable macroeconomic situation and dominant bank intermediation in the financial system. The acquirers, in turn, come from poorer countries with faster economic growth and relatively more market-oriented financial systems. Those results broadly conform with the predictions of three hypotheses formulated in the text. They form also a good base for future research since they indicate the external variables, which should be included in the formal models of divestiture decisions in banking.

\section{References}

1. Afshar, K.A., Taffler, R.J. \& Sudarsanam, P.S. (1992). The Effect of Corporate Divestments on Shareholder Wealth. The UK experience. Journal of Banking \& Finance, 16, 115-135.

2. Ahn, S. \& Denis, D.J. (2004). Internal capital markets and investment policy: evidence from corporate spinoffs. Journal of Financial Economics, 71, 489-516.
3. Brauer, M. (2006). What have we acquired and what should we acquire in divestiture research? A Review and Research Agenda, 32(6), 751-785.

4. Burch, T.R. \& Nanda, V. (2003). Divisional diversity and the conglomerate discount: evidence from spin-offs. Journal of Financial Economics, 70, 69-98.

5. Çolak, G. \& Whited, T.M. (2007). Spin-offs, divestitures, and conglomerate Investment. The Review of Financial Studies, 20(3), 557-595.

6. Decker, C. \& Mellewigt, T. (2007a). The drivers and implications of business divestiture - and application and extension of prior findings. SFB 649 Discussion Paper, Humboldt -Universität zu Berlin.

7. Decker, C. \& Mellewigt, T. (2007b). Thirty years after Michael E. Porter: What do we know about business exit? Academy of Management Perspectives, May, 41-55.

8. Denis, D.J., Denis, D.K. \& Sarin A. (1997). Agency problems, equity ownership, and corporate diversification. The Journal of Finance. 52(1), 135-160.

9. Denis, D.J. \& Kruse, T.A. (2000). Managerial discipline and corporate restructuring following performance declines. Journal of Financial Economics, 55, 391-424. 
10. Gleason, K.C., Mathur, I. \& Singh, M. (2000). Wealth effects for acquirers and divestors related to foreign divested assets. International Review of Financial Analysis, 9, 5-20.

11. Guedes, J. \& Parayre R. (1997). Managerial reputation and divisional sell-offs: A model and empirical test. Journal of Banking and Finance, 21, 10851106.

12. Hryckiewicz, A. \& Kowalewski, O. (2010). The determinants of the exit decisions of foreign banks. Banking and Finance Review, 2(2), 53-72.

13. Hryckiewicz, A. \& Kowalewski, O. (2011). Why do foreign banks withdraw from other countries. International Finance, 14, 67-102.

14. Leung, M., Young, T. \& Fung, M.K. (2008). The entry and exit decisions of foreign banks in Hong Kong. Managerial and Decision Economics, 29, 503-512.

15. Owen, S. \& Yawson, A. (2006). Domestic or international: Divestitures in Australian multinational corporations. Global Finance Journal, 17, 282-293.

16. Zhou, Y.M., Li, X. \& Svejnar, J. (2011). Subsidiary divestiture and acquisition in a financial crisis: Operational focus, financial constraints and ownership. Journal of Corporate Finance, 17, 272-287. 
